University of Michigan Law School University of Michigan Law School Scholarship Repository

2009

\title{
The Future of American Labor and Employment Law: Hopes, Dreams, and Realities
}

Theodore J. St. Antoine

University of Michigan Law School, tstanton@umich.edu

Available at: https://repository.law.umich.edu/articles/1451

Follow this and additional works at: https://repository.law.umich.edu/articles

Part of the Labor and Employment Law Commons, and the Legislation Commons

\section{Recommended Citation}

St. Antoine, Theodore J. "The Future of American Labor and Employment Law: Hopes, Dreams, and Realities." Emp. Responsibilities \& Rts. J. 21, no. 2 (2009): 133-8.

This Article is brought to you for free and open access by the Faculty Scholarship at University of Michigan Law School Scholarship Repository. It has been accepted for inclusion in Articles by an authorized administrator of University of Michigan Law School Scholarship Repository. For more information, please contact mlaw.repository@umich.edu. 


\title{
The Future of American Labor and Employment Law: Hopes, Dreams, and Realities
}

\author{
Theodore J. St. Antoine
}

Published online: 27 March 2009

(C) US Government 2009

Key words american labor employment law organized labor

In many respects the US is a deeply conservative country. Unique among the major industrial democracies of the world, it imposes the death penalty, provides no national health insurance, fixes a high legal drinking age, and subscribes to the doctrine of employment at will. Perhaps not surprisingly, its labor movement is also one of the most conservative on earth, eschewing class warfare and aiming largely at the bread-and-butter goal of improved wages, benefits, and working conditions. Yet American employers have generally never been as accepting of unionization as their counterparts in other countries (Bok 1971; Freeman and Medoff 1984). Over the last half century the density of unions in the private sector has fallen from about 35\% to 7.5\% (Bureau of Labor Statistics 1980, 2008). Employee apathy, vigorous employer opposition, and changing patterns of work have all played a part in that decline but this paper will focus on the role of law.

The sweeping victory of President-elect Barack Obama and the enhanced Democratic majorities in both houses of Congress will improve the chances for federal legislation favoring unions and working people. But success is not preordained. In 1976, when Jimmy Carter was elected President, the Democrats wound up with a 61-38 majority in the Senate (there was one independent) and a 149-member margin in the House. That might have seemed filibuster-proof but it wasn't. President Carter proposed a Labor Reform Act in 1977 that was carefully tailored to enable easier organizing of nonunion firms without changing the existing balance of bargaining power between unionized businesses and the unions representing their employees. The bill easily passed the House. Carter promised to persist until any filibuster in the Senate was broken. But after an unprecedented six attempts at cloture failed, the Administration gave up and the measure died (Congressional Quarterly Almanac 1978). Obama will not have as many Democrats in the Senate as Carter

T. J. St. Antoine $(\triangle)$

University of Michigan Law School, 625 South State Street, Ann Arbor, MI 48109-1215, USA

e-mail: tstanton@umich.edu 
had. As Senator, Obama co-sponsored one of the labor movement's fondest wishes, the socalled Employee Free Choice Act, discussed below. But as President, Obama will be confronting a grave economic crisis, with direct costs to the government in the trillion-dollar range. He has also made energy, heath care, and education top priorities. How much credit will he be prepared to expend on enacting labor legislation if hard choices have to be made?

In this paper I shall review some of the major proposals already before Congress concerning labor and employment regulation, and some of the ideas that I believe should be pursued to make regulation fairer and more effective. The American workforce is changing so radically, with more and more persons providing services who can hardly be classified as "employees" in the traditional sense, that sooner or later we may need dramatically new forms of regulating workers and those who engage their services (Hyde 2003; Stone 2008). But I shall first concentrate on efforts to improve the more conventional legislation dealing with union-employer-employee relations.

\section{Employee Free Choice Act}

The Employee Free Choice Act (EFCA) (H.R. 800, S. 1041 2007), or a bill much like it, will almost certainly be reintroduced in the new Congress. The original proposal contained two highly controversial provisions. The first would enable a union to secure exclusive bargaining rights if a majority of the employees sign written authorizations, without the need for a secret-ballot vote. The second would provide for binding arbitration of the terms of a labor contract, if an employer and a newly formed union cannot negotiate an agreement after 120 days of bargaining. Other provisions call for much stiffer sanctions in the event of employer violations during an organizing campaign or first-contract negotiations. Those include civil penalties up to $\$ 20,000$ for each willful or repeated company violation, treble back pay for victims of discrimination, and a requirement that the National Labor Relations Board (NLRB) seek preliminary injunctions against employer discrimination.

Disinterested observers have long decried the inadequacy of Labor Board remedies and the long delays in obtaining them as the worst defects of the National Labor Relations Act (NLRA) (Weiler 1900; St. Antoine 1968). For an obdurate employer (or union in certain situations), existing statutory remedies amount to a slap on the wrist and a license to continue the wrongdoing. There are plainly grounds for the stiffer sanctions proposed by EFCA for employer violations during an organizing drive or first-contract negotiations. According to one scholar, discriminatory discharges of union supporters increased as much as ten times in the decades following the relatively halcyon 1950s (Weiler 1900). The more problematic proposals are those providing for certification upon a majority's signing of bargaining authorizations and mandatory arbitration of contract terms if first-time negotiations fail.

Advocates of changes in the standard "paradigm" of an extended election campaign followed by a secret-ballot vote point to the opportunities it affords for employer coercion or intimidation of employees (Brudney 2005). Also emphasized is the current dismal state of organized labor at a time when strong unions are sorely needed to counter the increasing disparity in the incomes of the working class and the affluent top 5\%. Those are powerful and appealing arguments. But they cut against the American grain; we still have great faith in a secret vote as the surest guide to a person's free and untrammeled choice. We do not wish to substitute possible union coercion or intimidation-or the more subtle pressures exerted by fellow workers - for employer coercion or intimidation. One may also wonder about the effectiveness of a union in the subsequent bargaining if it could not muster the support of an employee majority in a secret election. Employers also have a legitimate 
interest in expressing their views about the effects of unionization on their business before the employees decide. Unless an employer agrees to a card check, or, conversely, commits unfair labor practices that make a fair election infeasible (see NLRB v. Gissel Packing Co. 1969), I would prefer to retain the secret vote in some fashion. It could be an election after a much shorter campaign time as proposed in the Labor Reform Act of 1977, which would minimize the opportunities for employer coercion. It might even be a provision enabling dissenting employees to obtain an election within a limited period of time after a union was installed through signed authorizations (compare Dana Corp. 2007).

Not so long ago unions as well as management would have regarded as anathema any governmentally imposed compulsory arbitration in the private sector (Ruben 2003). But as arbitration of contract terms became more accepted in the public sector in a number of states, especially for police and firefighters who could not be allowed to strike, much of organized labor changed its mind about the private sector. The AFL-CIO now strongly supports EFCA's provision for the arbitration of contract terms if an agreement cannot be secured within 120 days in a first-contract negotiation. Opponents will argue that this is totally contrary to the American tradition of free collective bargaining and the private setting of contract terms. One compromise might be to limit this provision to situations where the union cannot strike as a practical matter, because workers can be replaced so easily, or automation is so pervasive, or the business is so vital to the public health and safety that strikes of any duration cannot be tolerated. Communications and transportation are obvious examples. Another alternative, as proposed in the Labor Reform Act of 1977, would be to authorize the NLRB to prescribe a make-whole remedy when an employer violates the statutory duty to bargain in first-contract negotiations. The latter sanction would not constitute a continuing contract, but would be compensatory relief based on the employees' lost wages and benefits, as measured by the statistics of comparable labor agreements. Payments would continue until the employer resumed bargaining in good faith. I would argue further that a make-whole remedy should extend, not just to first-time negotiations, but to any situation in, which an employer commits a clear and egregious violation of the duty to bargain. That sort of remedy is the only kind with any bite. The Labor Board's current order to bargain amounts to little more than a pious exhortation to go and sin no more.

\section{Other NLRA Reforms}

As it currently exists and is administered, the NLRA appears incapable of fulfilling what remains the official policy of the US, namely, "encouraging the practice and procedure of collective bargaining" (NLRA 1935). Various scholars have proposed a range of improvements beyond those contained in EFCA (Craver 1993; Weiler 1900). To begin with, the coverage of "employees" is too narrow. The Act expressly excludes agricultural workers. With the demise of the family firm and the growth of agribusiness, that makes no sense. The Supreme Court in 5-4 decisions has further reduced coverage by extending the concept of supervisory and managerial personnel to include nurses who direct less-skilled employees in hospitals and faculty members in so-called "mature" private universities (NLRB v. Kentucky River Community Care, Inc. 2001; NLRB v. Yeshiva University 1980). Those rulings would seem to reflect more a particular judicial philosophy than a realistic appraisal of hierarchical relationships in the workforce. Corrective legislation is needed here and in other areas where the term "employee" has been too stingily and unrealistically applied. 
Lack of access to the workplace for communicating the merits of unionization puts labor organizations at a severe disadvantage vis-à-vis employers. Here property rights have been exalted over worker rights. Long ago, in dictum, the Supreme Court recognized that union organizers might have to be allowed to reach employees on company property when it is in an isolated location (Republic Aviation Corp. v. NLRB 1945; compare Lechmere, Inc. v. $N L R B$ 1992). For all practical purposes, a large plant in a metropolitan area, where employees disperse widely at the end of the workday, might almost as well be a remote lumber camp. The workplace is the natural forum for debating the pros and cons of unionization. But if American property rights are too dominant to permit any general union access in such cases, at least, as Derek Bok of Harvard once proposed, the law should allow a union equal time to respond on company premises when an employer resorts to the powerful weapon of a "captive audience" speech to employees within the last week or so of an election campaign (Bok 1964).

Although an employer cannot "discharge" employees who exercise their statutory right to strike, it may "permanently replace" them in order to carry on its business (TWA $v$. Independent Federation of Flight Attendants 1989). That is a distinction only a lawyer, and certainly not a blue-collar worker, can understand. Especially in times of widespread unemployment, the threat of permanent replacement has a chilling effect on the right to strike. Speaking with diplomatic delicacy, a committee of the International Labor Organization (ILO) has declared that permanent replacement "entails a risk of derogation from the right to strike, which may affect the free exercise of trade union rights" (International Labor Organization 1991). The conclusion was that the US may be in violation of the ILO Constitution. Unless a company can clearly demonstrate that its survival is at stake, the permanent replacement of strikers should be forbidden.

Another overdue change in the NLRA would loosen the restrictions of the secondary boycott ban to permit unions to follow a "struck product" from the plant and ask retail employees and customers not to handle or purchase it. That is no more than what would occur if the strike successfully closed down the plant. Such activity is thus a natural extension of the lawful "primary" strike (Lesnick 1962). It would not permit a boycott of the second retailer as such. Bargaining should also be required on any lawful matter that either union or employer wishes to bring to the table. Experienced negotiators in mature relationships scoff at the artificial legal distinctions that have been drawn between "mandatory" and "permissive" subjects of bargaining (see NLRB v. Wooster Division of Borg-Warner Corp. 1958). Frank and open exchanges are the goal. Finally, Section 8(a)(2) of the NLRA, which forbids employer interference with a union, should be reinterpreted or revised to enable employees, either union or nonunion, to engage in innovative methods of collaboration with their employers, as long as the employees have chosen this option freely and knowingly. Such cooperation could have both a psychic and a financial payoff for all involved.

\section{Civil Rights Law}

Title VII of the Civil Rights Act of 1964 and other laws prohibiting discrimination in employment have one glaring deficiency. Their coverage is limited to "employees." There may be very good reasons to define the scope of the wage and hour laws and workers' compensation laws in terms of employees. There seems no sound reason that a person seeking someone to furnish services, whether an "employee" or an "independent contractor," should be able to discriminate because of race, sex, religion, age, disability, or similar arbitrary grounds. Civil rights legislation ought to be broadened accordingly. 


\section{Wrongful Discharge}

The US is the last major industrial democracy in the world that still adheres to the doctrine of employment at will. As stated in a famous 19th century decision, that means an employer may discharge employees "for good cause, for no cause or even for cause morally wrong" (Payne v. Western \& Atlantic Railroad Co. 1884). Civil rights statutes, the NLRA, and judicial rulings in nearly all the states have carved out exceptions based on an employee's status or union activities, on express or implied contract, and on public policy grounds. But employment at will remains the basic principle. An employer can fire an employee because of mere personal whim, and in most states even because of political beliefs. In 1991 the Uniform Law Commissioners (ULC) adopted the Model Employment Termination Act (META) by a 39-11 vote of the state delegations. META would have protected most fulltime employees (working 20 or more hours a week) after 1 year of service against discharge without "good cause." Despite the approval by a substantial majority of the prestigious ULC, however, no state has passed META. The present economic climate and the interstate competition for business make states wary about taking the lead in this sort of social legislation. That may leave the task for Congress. I would say that this is a moral imperative, to which the US must eventually respond, but in these turbulent times I would not expect action soon.

If and when Congress does make wrongful discharge an unfair employment practice, or otherwise prohibits it, how should the new law be enforced? META's preference was for the states to use the well-established body of professional labor arbitrators. The Federal Mediation and Conciliation Service's panel of arbitrators, somewhat expanded, could be the federal answer. An alternative would be to merge the NLRB and the Equal Employment Opportunity Commission (EEOC) into a single 7- or 9-member National Labor and Employment Board (NLEB), with responsibility for handling all these interstate unionemployer-employee disputes outside the transportation industries (covered separately by the Railway Labor Act 1926). Over time, the discrimination cases handled by the EEOC should dwindle significantly, which would make a merger quite appropriate. Preferably, the new NLEB's orders would be self-enforcing, subject of course to review by the US courts of appeals, but at least the Board, like the EEOC at present, ought to have the authority to sue on behalf of claimants in the federal district courts.

\section{More Radical Scenario}

Scholars like Katherine Van Wezel Stone of UCLA have suggested, in effect, that much of the above agenda may be reminiscent of rearranging the deck chairs on the Titanic (Stone 2008; see also Weiler 1900). They envisage the possibility that unions will continue to decline and that worker rights will atrophy unless there are radical changes in our labor and employment law. One alternative approach would be for much broader social legislation to replace the void left by the loss of traditional collective bargaining. Worker protection would expand beyond wages, hours, physical safety, and nondiscrimination to cover such areas as health care, training and education, intellectual property, pensions, and even housing. Another approach would be to mandate employee involvement (EI) programs for all larger companies. These would ensure a direct employee voice in the operations of the workplace, whether or not a union existed, and even in situations where employees did not want a union. Employers would be obligated to discuss any subject raised by worker representatives elected by the employees, but there would be no duty to seek agreement. 
Such a system would be an extension of the EI programs that have been adopted voluntarily by many sophisticated US companies, both union and nonunion. In an intensely competitive global market, employee input about improving quality and productivity can be highly beneficial.

\section{Conclusion}

Despite the natural conservatism of the US in socioeconomic matters, some major changes in labor and employment law seem inevitable. If there is not legislation to reverse the downward slide of organized labor, there will have to be substantial new social legislation to substitute for what collective bargaining has provided in the past. Ideally, there should be both-legislation to spur a resugence of unions, and legislation to secure an appropriate economic safety net for all workers, whatever their disposition toward union organization.

\section{References}

Bok, D. (1964). The regulation of campaign tactics in representation elections under the National Labor Relations Act. Harvard Law Review, 78, 38-141.

Bok, D. (1971). Reflections on the distinctive character of American labor law. Harvard Law Review, 84, $1394-1463$.

Brudney, J. (2005). Neutrality agreements and card check recognition: prospects for changing paradigms. Iowa Law Review, 90, 819-886.

Bureau of Labor Statistics, US Department of Labor (1980). Bulletin No. 2070, Handbook of Labor Statistics.

Bureau of Labor Statistics, US Department of Labor (2008). USDL 08-0092, News.

Craver, C. (1993). Can unions survive? The rejuvenation of the American labor movement. New York: New York University Press.

Dana Corp., 351 N.L.R.B. No. 28 (NLRB 2007).

Employee Free Choice Act. 2007, H. R. 800, S. 1041, 110th Congress, 1st Session.

Freeman, R., \& Medoff, J. (1984). What do unions do?. New York: Basic Books.

Hyde, A. (2003). Working in Silicon Valley: Economic and legal analysis of a high-velocity labor market. Armonk: M.E. Sharpe.

International Labor Organization, Committee on Freedom of Association (1991). Report No. 278, Case No. 1543. Labor Reform Act 1977, H.R. 8140, S. 1883, 95th Congress, 1st Session.

Lechmere, Inc. v. NLRB, 502 U.S. 527 (S. Ct. 1992).

Lesnick, H. (1962). The gravamen of the secondary boycott. Columbia Law Review, 62, 1363-1430.

Model Employment Termination Act 1991. Uniform Laws Annotated, 7A, 428.

National Labor Relations Act 1935, 29 U.S.C. § 151.

NLRB v. Wooster Division of Borg-Warner Corp., 356 U.S. 342 (S. Ct. 1958).

NLRB v. Gissel Packing Co., 395 US 575 (S. Ct. 1969).

NLRB v. Kentucky River Community Care, Inc., 532 U.S. 706 (S. Ct. 2001).

NLRB v. Yeshiva University, 444 U.S. 672 (S. Ct. 1980).

Payne v. Western \& Atlantic Railroad Co., 81 Tenn. 507 (Tenn. S. Ct. 1884).

Railway Labor Act 1926, 45 U.S.C. \$151.

Republic Aviation Corp. v. NLRB, 324 U.S. 793 (S. Ct. 1945).

Ruben, A. (2003). Elkouri \& Elkouori: How arbitration works (6th ed.). Washington, D.C.: Bureau of National Affairs.

St. Antoine, T. (1968). A touchstone for Labor Board remedies. Wayne Law Review, 14, 1039-1058.

Stone, K. (2008). The future of labor and employment law in the United States. In Encyclopedia of Labor and Employment Law and Economics. Williston: Edward Elgar.

Title VII of the Civil Rights Act 1964, 42 U.S.C. § 2000e.

TWA v. Independent Federation of Flight Attendants, 489 U.S. 426 (S. Ct. 1989).

Weiler, P. (1900). Governing the workplace: The future of labor and employment law. Cambridge: Harvard University Press. 
Reproduced with permission of the copyright owner. Further reproduction prohibited without permission. 